\title{
METODE PENGEMASAN TAUGE KACANG HIJAU MENGGUNAKAN PLASTIK POLIETILIN DAN POLIPROPILIN PADA PENYIMPANAN SUHU RENDAH
}

\section{PACKAGING METHOD OF GREEN NUTS TAUGE USING POLYETHYLENE AND POLYPROPYLENEH PLASTIC AT LOW TEMPERATURE STORAGE}

\author{
Ansar $^{1 凶}$, Sukmawaty $^{1}$, Murad $^{1}$, Isna Hilda Arini ${ }^{1}$ \\ ${ }^{1}$ Program Studi Teknik Pertanian, Fakultas Teknologi Pangan dan Agroindustri, Universitas Mataram

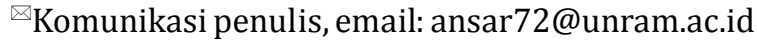 \\ DOI:http://dx.doi.org/10.23960/jtep-l.v10i1.119-128
}

Naskah ini diterima pada 3 Maret 2021; revisi pada 23 Maret 2021; disetujui untuk dipublikasikan pada 23 Maret 2021

\begin{abstract}
Green bean sprouts are a type of vegetable that has a short shelf life. To extend the shelf life of these vegetables, they need to be stored by appropriate packaging methods. The aim of this study was to apply polyethylene (PE) and polypropylene (PP) plastic packaging to increase the shelf life of mung bean sprouts. The research was conducted by packing mung bean sprouts in PE and PP plastic at storage temperatures of 10 and $29^{\circ} \mathrm{C}$ for 9 days. The parameters observed were weight loss, respiration rate, color, moisture content, and aroma. The results showed that mung bean sprouts stored in PE packaging had a longer shelf life than PP packaging. The shelf life of mung bean sprouts using PE packaging is 5 days, while PP packaging can only last 3 days at $10^{\circ} \mathrm{C}$. The shelf life of mung bean sprouts using PE packaging is 4 days, while the PP packaging can only last 2 days at $29^{\circ} \mathrm{C}$.
\end{abstract}

Keywords: green bean sprouts, packaging, PE plastic, storage, temperature

\begin{abstract}
ABSTRAK
Tauge kacang hijau termasuk jenis sayuran yang memiliki umur simpan pendek. Guna memperpanjang umur simpan sayuran ini, maka perlu disimpan dengan metode pengemasan yang tepat. Tujuan penelitian ini adalah mengaplikasikan kemasan plastik polietilin (PE) dan polipropilin (PP) untuk meningkatkan umur simpan tauge kacang hijau. Penelitian dilakukan dengan mengemas tauge kacang hijau dalam plastik PE dan PP pada suhu penyimpanan 10 dan $29^{\circ} \mathrm{C}$ selama 9 hari. Parameter yang diamati adalah susut bobot, laju respirasi, warna, kadar air, dan aroma. Hasil penelitian menunjukkan bahwa tauge kacang hijau yang disimpan pada kemasan PE memiliki umur simpan yang lebih lama dibandingkan dengan kemasan PP. Umur simpan tauge kacang hijau menggunakan kemasan PE adalah 5 hari, sedangkan pada kemasan PP hanya mampu bertahan 3 hari pada suhu $10^{\circ} \mathrm{C}$. Umur simpan tauge kacang hijau menggunakan kemasan PE adalah 4 hari, sedangkan pada kemasan PP hanya mampu bertahan 2 hari pada suhu $29^{\circ} \mathrm{C}$.
\end{abstract}

Kata kunci: tauge kacang hijau, kemasan, plastik PE, penyimpanan, suhu

\section{PENDAHULUAN}

Tauge kacang hijau merupakan jenis sayuran yang tumbuh dari biji kacang hijau melalui perkecambahan. Permasalahan pada tauge kacang hijau adalah memiliki umur simpan yang pendek apabila disimpan pada suhu ruang. Tauge ini mudah berubah menjadi kecoklatan jika disimpan terlalu lama (Nurmiati \& Gazali, 2019), yang dapat berakibat pada warna dan tekstur menjadi tidak menarik dan harga jualnya pun semakin murah (Cahyanto et al., 2019).

Pada dasarnya tauge kacang hijau setelah dipanen masih memiliki jaringan hidup, sehingga proses respirasi dan transpirasi masih terus berlangsung (Akmal et al., 2020). Adanya respirasi yang tinggi dapat menyebabkan tauge kacang hijau menjadi layu dan busuk (Lisa et al., 2016). 
Metode penyimpanan bahan hasil pertanian pada kondisi yang tidak sesuai dapat menyebabkan kerusakan fisiologis pada bahan. Kerusakan fisiologis dapat terjadi karena pengaruh suhu lingkungan yang tidak sesuai atau karena kekurangan nutrisi selama pertumbuhan (Arrashid et al., 2020). Beberapa jenis kerusakan fisiologis yang sering terjadi, misalnya kerusakan karena suhu rendah (chilling injury), kerusakan karena suhu beku (freezing injury), kerusakan karena suhu tinggi, kerusakan karena $\mathrm{CO}_{2}$ yang tinggi dan $\mathrm{O}_{2}$ yang terlalu rendah, serta kerusakan karena defisiensi mineral selama pertumbuhan (Ansar et al., 2019).

Salah satu metode yang digunakan untuk mengurangi kerusakan akibat kehilangan air dan dehidrasi pada produk segar adalah plastik (Mareta \& Shofia, 2011). Beberapa peneliti telah membuktikan bahwa pengemasan dapat mencegah kerusakan pada bahan pangan dan sebagai bahan pelindung dari kontaminasi dengan zat pencemar (Aulia et al., 2019).

Bahan pengemasan yang sudah umum digunakan untuk pengemasan produk hortikultura adalah plastik polyethylene (PE). Plastik PE memiliki tekstur yang lunak, transparan dan fleksibel, mempunyai kekuatan benturan dan kekuatan sobek yang baik (Nurhidajah \& Kumalasari, 2011). Plastik PE dapat meningkatkan konsentrasi $\mathrm{CO}_{2}$ dan menurunkan konsentrasi $\mathrm{O}_{2}$, sehingga proses kerusakan bahan dapat dihambat (Anggraini \& Sugiarti, 2018). Permeabilitas terhadap gas $\mathrm{O}_{2}$ dan $\mathrm{CO}_{2}$ semakin berkurang dengan semakin tebalnya plastik (Ansar et al., 2019). Dwi et al. (2013) menyatakan bahwa konsentrasi $\mathrm{CO}_{2}$ pada ketebalan plastik PE $0,04 \mathrm{~mm}$ dapat menghambat proses pembusukan dan kelayuan sayur bunga kol. Bahan kemasan lain yang sering digunakan adalah plastik polyprophylene (PP). Plastik PP memiliki ketahanan yang baik terhadap lemak serta daya tembus uap yang rendah, memiliki densitas yang lebih rendah dan titik lunak lebih tinggi dibandingkan dengan plastik PE (Mareta \& Shofia 2011).

Faktor lain yang berpengaruh terhadap umur simpan sayur-sayuran adalah suhu dan kelembaban. Suhu yang tinggi dapat mempercepat proses pelayuan karena terjadinya penguapan kadar air. Hasil penelitian Rahmawat (2015) melaporkan bahwa tauge kacang hijau yang dikemas dengan plastik PE memiliki umur simpan 18 hari pada suhu 11,8 ${ }^{\circ} \mathrm{C}$, sedangkan penelitian Wulandari et al. (2013) melaporkan bahwa tingkat kerusakan tauge kacang hijau dapat dihambat menggunakan plastik PE.

Selama ini metode penyimpanan yang sering dilakukan untuk mempertahankan masa simpan produk hortikultura adalah menggunakan refrigerator. Namun, metode ini membutuhkan biaya operasional yang mahal dan tidak cocok digunakan bagi penjual sayur dan buah. Guna mengatasi permasalahan ini, maka perlu dicarikan metode lain yang dapat mempertahankan mutu produk dan dapat menghambat pertumbuhan mikroba parasit dan bakteri selama penyimpanan. Oleh karena itu, tujuan penelitian ini adalah mengaplikasikan kemasan plastik PE dan PP untuk meningkatkan umur simpan tauge kacang hijau.

\section{BAHAN DAN METODE}

Bahan yang digunakan adalah tauge kacang hijau yang telah disortasi kemudian disimpan dalam kemasan plastik PE dan PP masing-masing berukuran 15 × $27 \mathrm{~cm}$ dengan ketebalan 0,003 $\mathrm{cm}$. Peralatan yang digunakan adalah timbangan digital merk Mettler Toledo, refraktometer, moisture tester, cawan petri, thermometer, colorimeter, refrigerator, tupperware, stopwatch, kamera digital, buret, labu ukur, erlenmeyer, oven, desikator, cawan porselen, dan pH meter.

\subsection{Prosedur Penelitian}

Tauge kacang hijau sebanyak 500 gram dikemas menggunakan plastik PE dan PP kemudian disimpan pada suhu 10 dan $29^{\circ} \mathrm{C}$ selama 9 hari. Melakukan pengamatan susut bobot, laju respirasi, warna, kadar air, dan aroma setiap hari selama penyimpanan.

Pengukuran warna dilakukan menggunakan color meter. Data warna dinyatakan dengan nilai L (kecerahan), nilai a* (warna kromasitas merah-hijau), dan nilai $b^{*}$ (warna kromasitas 
biru-kuning). Pengujian parameter aroma dilakukan menggunakan uji kesukaan (Ansar et al., 2019). Panelis yang digunakan adalah 20 orang mahasiswa untuk memberikan penilaian terhadap aroma tauge kacang hijau dengan mengisi formulir yang telah disediakan. Skor uji aroma dinyatakan dalam angka 1 = sangat tidak suka, 2 = tidak suka, 3 = agak suka, $4=$ suka, dan $5=$ sangat suka.

Pengukuran kadar air menggunakan metode oven (AOAC, 2016). Sampel sebanyak 2 gram dipanaskan pada suhu $105{ }^{\circ} \mathrm{C}$ selama 8 jam, kemudian didinginkan dalam desikator selama 1 jam dan ditimbang. Sampel dipanaskan kembali selama 1 jam kemudian ditimbang sampai diperoleh bobot tetap tidak lebih dari 0,0002 gram. Kadar air dihitung dengan persamaan (Ansar et al., 2012):

$$
\text { kadar air }=\frac{b-c}{b-a} \times 100 \%
$$

dengan, a adalah berat cawan kosong, $\mathrm{b}$ adalah berat cawan + sampel awal, c adalah berat cawan + sampel setelah dikeringkan.

Pengukuran laju respirasi dilakukan dalam kemasan plastik PE dan PP yang telah disealer mengikuti prosedur yang telah dilakukan oleh Rina (2012). Dimasukkan sampel sebanyak 300 g. Diberikan lubang yang ditutup dengan karet untuk pengambilan sampel gas. Bagian lubang ditutup dengan lem agar tidak bocor. Kemasan disimpan pada suhu kamar. Pengambilan sampel laju respirasi dilakukan setiap hari selama 9 hari. Setelah diperoleh data konsentrasi gas (\%) pada setiap kemasan, selanjutnya dikalikan dengan volume kemasan, sehingga didapatkan hasil pengukuran perubahan konsentrasi $\mathrm{O}_{2}$ dan $\mathrm{CO}_{2}$ dalam satuan ml. Untuk perhitungan laju respirasi, maka laju perubahan gas dalam $\mathrm{ml} /$ jam dibagi dengan berat sampel pada setiap kemasan, sehingga diperoleh data laju respirasi dalam satuan $\mathrm{ml} / \mathrm{jam} / \mathrm{g}$ atau dengan persamaan:

$$
\text { Laju respirasi }=\frac{(\text { blanko }- \text { sampel }) \times 0,1 \times 44}{\text { berat bahan }}
$$

dengan, blanko adalah respirasi tanpa bahan, sampel adalah respirasi menggunakan bahan, 0,1 merupakan konsentrasi $\mathrm{HCl}$, dan 44 merupakan berat molekul $\mathrm{CO}_{2}$.
Pengukuran susut bobot sampel dilakukan dengan cara menimbang berat sampel sebelum dan sesudah penyimpanan. Selanjutnya ditimbang lagi pada interval waktu 1 hari sampai terjadi pembusukan sebagai berat akhir. Perhitungan susut bobot menggunakan persamaan (Ansar et al., 2020):

$$
\text { susut bobot }=\frac{\mathrm{B} 0-\mathrm{Bt}}{\mathrm{B} 0} x 100 \%
$$

dengan, Bt adalah Bobot sampel pada hari ke-n (gram), B0 adalah bobot awal sampel pada hari ke-0 (gram).

\subsection{Analisis Data}

Data yang dihasilkan dari penelitian ini dianalisis menggunakan analisis sidik ragam. Apabila nilai F-hitung lebih besar dari pada F-Tabel berarti terdapat pengaruh yang signifikan antara variabel bebas dengan variabel terikat (Ansar et al., 2006).

\section{HASIL DAN PEMBAHASAN}

\subsection{Susut Bobot}

Hasil penelitian susut bobot tauge kacang hijau selama penyimpanan ditunjukkan pada Gambar 1. Data pada Gambar 1 terlihat bahwa tauge kacang hijau mengalami perubahan susut bobot selama penyimpanan. Susut bobot semakin meningkat terjadi seiring dengan lamanya penyimpanan. Sampel tanpa kemasan (control) mengalami susut bobot tertinggi pada penyimpanan suhu $29^{\circ} \mathrm{C}$ yaitu $77,99 \%$ jika dibandingkan dengan tauge kacang hijau yang dikemas menggunakan plastik PE dan PP. Hal ini diduga karena sampel yang disimpan pada suhu $29^{\circ} \mathrm{C}$ tanpa pengemasan terjadi proses penguapan kadar air yang cepat. Hal ini sejalan dengan hasil penelitian Purnomo et al. (2017) bahwa kehilangan susut bobot pada bahan selama penyimpanan dapat disebabkan oleh sebagian air dalam jaringan bahan telah menguap yang menyebabkan pelayuan dan kekeringan.

Tauge kacang hijau yang disimpan pada kemasan PE dan PP pada suhu $29^{\circ} \mathrm{C}$ diperoleh susut bobot yang lebih kecil yaitu hanya sebesar 7,23 dan $8.38 \%$. Hal ini disebabkan adanya perlindungan dari kemasan selama penyimpanan. Data ini menunjukkan penggunaan kemasan dapat 
mengurangi susut bobot karena mampu mengurangi proses respirasi pada bahan. Selain itu, uap air juga dapat tertahan dan masih tertampung di dalam kemasan.

Penurunan susut bobot pada suhu $10{ }^{\circ} \mathrm{C}$ menggunakan kemasan PE dan PP yaitu sebesar 3,70 dan 5,11\%. Rendahnya susut bobot yang diperoleh pada kemasan PE pada penyimpanan suhu $10^{\circ} \mathrm{C}$ dipengaruhi oleh sifat bahan kemasan yang mempunyai permeabilitas rendah terhadap uap air, yaitu $0,185 \mathrm{~g} / \mathrm{m}^{2}$, sehingga dapat meningkatkan kelembaban dalam kemasan. Kelembaban udara yang tinggi di dalam kemasan PE justru dapat mempertahankan kadar air tauge kacang hijau.

Hal lain yang perlu dijelaskan adalah semakin lama penyimpanan, semakin meningkat pula susut bobot tauge kacang hijau karena telah terjadi penguapan kadar air. Peningkatan susut bobot salah satunya disebabkan oleh laju respirasi yang terjadi pada tauge kacang hijau. Hal yang sama pernah diungkap oleh Lamona et al. (2015) bahwa susut bobot yang semakin meningkat selama penyimpanan menunjukkan proses respirasi bahan juga semakin meningkat. Proses respirasi mengakibatkan kehilangan substrat dan air, sehingga terjadi perubahan susut bobot selama penyimpanan (Ansar et al., 2020).

\subsection{Laju Respirasi}

Data penelitian laju respirasi tauge kacang hijau selama penyimpanan disajikan pada Gambar 2. Selama penyimpanan terjadi perubahan laju respirasi pada semua perlakuan (Gambar 2). Laju respirasi tertinggi terjadi pada sampel tanpa kemasan dengan puncak respirasi terjadi pada hari ke- 5 yaitu sebesar $0.97 \mathrm{ml} / \mathrm{jam} / \mathrm{g}$, kemudian turun kembali pada hari ke-9 yaitu $0,50 \mathrm{ml} / \mathrm{jam} /$ g. Perbedaan laju respirasi ini disebabkan oleh suhu lingkungan. Pada penyimpanan suhu $29^{\circ} \mathrm{C}$ dengan kemasan PE dan PP mengalami puncak laju respirasi pada hari ke-5 yaitu sebesar 0,64 dan $0,68 \mathrm{ml} / \mathrm{jam} / \mathrm{g}$. Data ini menunjukkan bahwa laju respirasi tauge kacang hijau mengalami peningkatan setiap kenaikkan suhu $10^{\circ} \mathrm{C}$, sehingga proses pembusukan terjadi lebih cepat.

Laju respirasi tauge kacang hijau pada penyimpanan suhu $10{ }^{\circ} \mathrm{C}$ menggunakan kemasan PE dan PP meningkat pada hari ke-5 yaitu sebesar 0,46 dan $0,53 \mathrm{ml} / \mathrm{jam} / \mathrm{g}$ dan turun kembali pada hari ke-9 sebesar 0,34 dan 0,37 $\mathrm{ml} / \mathrm{jam} / \mathrm{g}$. Data ini menunjukkan bahwa laju respirasi terendah terdapat pada penyimpanan menggunakan kemasan PE pada suhu $10{ }^{\circ} \mathrm{C}$. Hasil ini sejalan dengan laporan Ansar et al. (2011) yang menyatakan bahwa penyimpanan suhu rendah dapat menekan laju respirasi, sehingga daya simpan buah atau sayur dapat diperpanjang.

Data hasil penelitian ini telah membuktikan bahwa laju respirasi suatu bahan dapat dijadikan indikator aktivitas metabolisme jaringan pasca panen. Data laju respirasi dapat digunakan untuk memprediksi umur simpan bahan. Semakin tinggi laju respirasi bahan, semakin pendek umur simpan bahan tersebut. Beberapa hasil penelitian juga telah mengungkapkan bahwa bahan yang memiliki laju respirasi yang tinggi pada umumnya memiliki umur simpan yang pendek (Hasbullah, 2007).

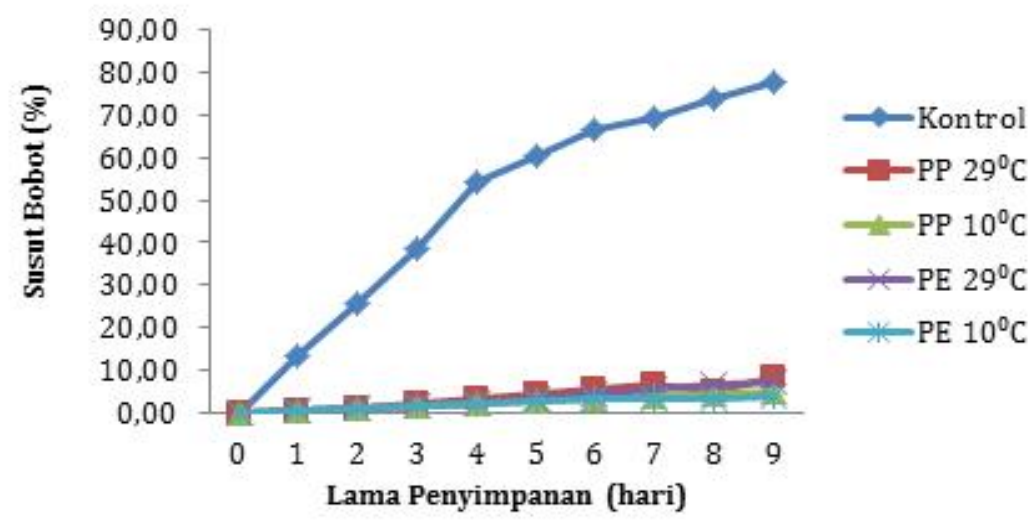

Gambar 1. Hubungan Antara Lama Penyimpanan Terhadap Susut Bobot Tauge Kacang Hijau 
Faktor yang berpengaruh terhadap besarnya laju respirasi pada sayuran adalah suhu penyimpanan. Semakin tinggi suhu penyimpanan, maka laju respirasi semakin meningkat. Faktor lain yang berpengaruh terhadap laju respirasi adalah jumlah $\mathrm{O}_{2}$ yang tersedia. Semakin lama waktu penyimpanan, maka konsumsi $\mathrm{O}_{2}$ semakin kecil. Hal ini sesuai dengan pendapat Imamah et al. (2016) yang menyatakan bahwa penyimpanan pada suhu rendah dapat menekan laju respirasi, sehingga umur simpan bahan dapat lebih lama.

\subsection{Warna Tauge Kacang Hijau}

\section{a. Kecerahan ( $\left.\mathrm{L}^{*}\right)$}

Hasil penelitian tentang warna kecerahan tauge kacang hijau selama penyimpanan ditunjukkan pada Gambar 3. Warna kecerahan tauge kacang hijau pada setiap perlakuan mengalami penurunan selama penyimpanan. Hal ini menandakan bahwa warna tauge kacang hijau semakin gelap seiring dengan lamanya penyimpanan dan terjadi pembentukan warna coklat sebagai akibat dari reaksi pencoklatan dengan enzim dan oksigen. Nilai kecerahan yang disimpan pada suhu $10{ }^{\circ} \mathrm{C}$ menggunakan kemasan PE sebesar 57,66 dan kemasan PP sebesar 56,07. Sedangkan penyimpanan pada suhu $29^{\circ} \mathrm{C}$ menggunakan kemasan PE sebesar 50,18 dan PP sebesar 48,76. Nilai kecerahan tauge kacang hijau tertinggi terdapat pada kemasan PE yang disimpan pada suhu $10{ }^{\circ} \mathrm{C}$ dengan nilai sebesar 57,66. Sedangkan nilai kecerahan terendah terdapat pada hari ke-9 penyimpanan diperoleh pada sampel tanpa kemasan dengan nilai sebesar 37,35.

\section{b. Kromasitas Hijau-merah (a*)}

Data hasil penelitian tentang kromasitas hijaumerah tauge kacang hijau selama penyimpanan disajikan pada Gambar 4. Data pada Gambar 4 menunjukkan bahwa kromasitas hijau-merah tauge kacang hijau semakin meningkat seiring

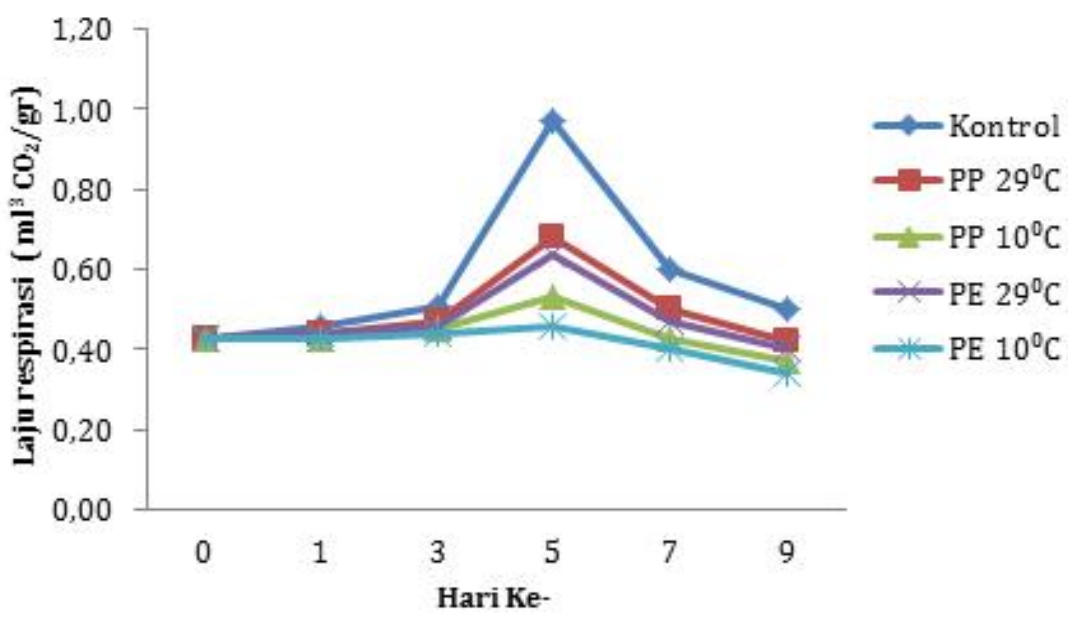

Gambar 2. Hubungan Lama Penyimpanan Terhadap Laju Respirasi Tauge Kacang Hijau

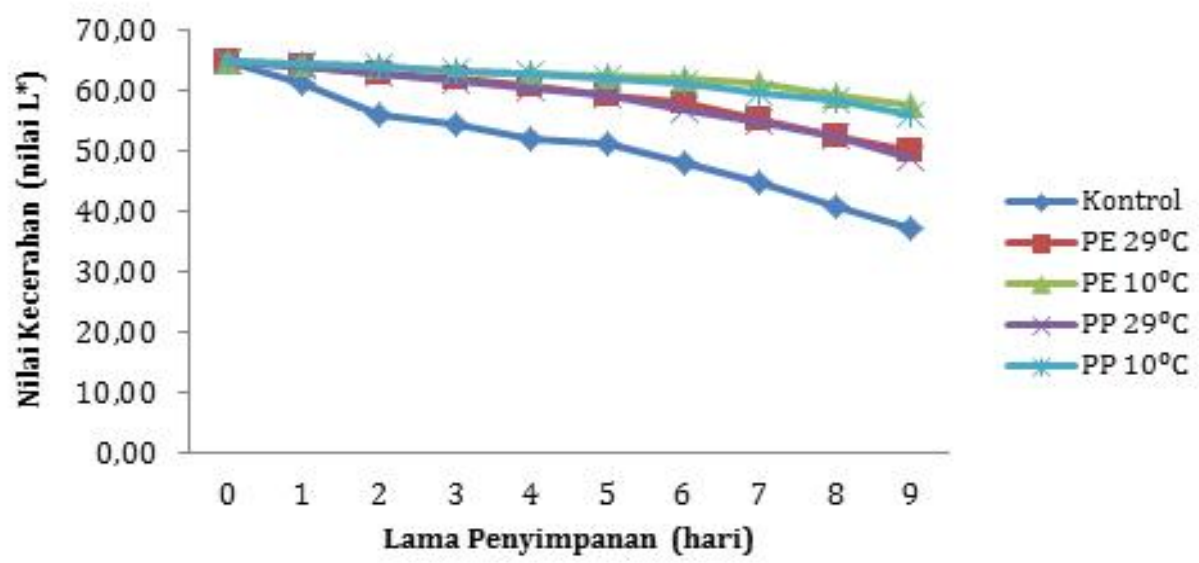

Gambar 3. Hubungan Lama Penyimpanan Terhadap Warna Kecerahan Tauge Kacang Hijau 
dengan lamanya penyimpanan. Hal ini menandakan bahwa semakin lama tauge kacang hijau disimpan, semakin cepat proses pembusukan. Tauge kacang hijau yang berwarna kemerahan berarti sudah hampir rusak. Tauge kacang hijau yang disimpan pada suhu $10{ }^{\circ} \mathrm{C}$ dengan kemasan PE diperoleh nilai kromasitas hijau-merah sebesar 8,61 dan kemasan PP sebesar 9,10. Pada penyimpanan suhu $29{ }^{\circ} \mathrm{C}$ dengan kemasan PE diperoleh nilai sebesar 11,50, kemasan PP sebesar 12,51, dan sampel tanpa kemasan sebesar 19,71.

Angka kromasitas hijau-merah yang semakin tinggi disebabkan oleh semakin menurunnya zat klorofil yang ada pada tauge kacang hijau, sehingga proses metabolisme dan pematangan semakin meningkat setiap hari. Peningkatan suhu dan lama penyimpanan juga dapat menyebabkan penurunan angka kromasitas hijau-merah. Suhu penyimpanan yang lebih rendah cenderung lebih lama bertahan dibandingkan dengan suhu yang lebih tinggi. Hal yang sama pernah diungkap oleh Ansar et al. (2020) bahwa kenaikan kromasitas hijau-merah dipengaruhi oleh proses respirasi, penguapan air, dan degradasi zat warna bahan.

\section{c. Kromasitas Kuning-biru (b*)}

Hasil penelitian kromasitas kuning-biru tauge kacang hijau selama penyimpanan disajikan pada Gambar 5. Data pada Gambar 5 menunjukkan bahwa rata-rata nilai $b^{*}$ pada penyimpanan suhu $10{ }^{\circ} \mathrm{C}$ menggunakan kemasan PE dan PP mengalami kenaikkan setelah disimpan selama 9 hari yaitu sebesar
25,01 dan 25,08. Sedangkan pada suhu $29{ }^{\circ} \mathrm{C}$ untuk kemasan PE dan PP sebesar 26,15 dan 26,32 . Kenaikkan nilai b* tertinggi terdapat pada sampel tanpa kemasan yaitu sebesar 28,79. Nilai kromasitas kuning-biru yang semakin meningkat menandakan bahwa tauge kacang hijau sudah mulai mengalami perubahan warna selama penyimpanan. Hal ini sesuai dengan pendapat Akmal et al. (2020) bahwa pencoklatan merupakan proses pembentukan pigmen berwarna kuning dan segera berubah menjadi warna coklat gelap. Pembentukan warna coklat ini dipicu oleh adanya reaksi oksidasi oleh enzim fenol oksidase. Penyimpanan pada suhu $10{ }^{\circ} \mathrm{C}$ dapat memperlambat proses penguapan air, perombakan zat warna, dan pematangan buah, sehingga perubahan warna dapat diperlambat.

\subsection{Kadar Air}

Pengukuran kadar air bertujuan untuk mengetahui kesegaran tauge kacang hijau selama penyimpanan karena kadar air diduga sangat berpengaruh terhadap kesegaran dan daya tahan terhadap produk. Akan tetapi, kadar air yang tinggi dapat menyebabkan susut bobot produk yang tinggi. Hasil penelitian kadar air tauge kacang hijau selama penyimpanan disajikan pada Gambar 6.

Berdasarkan data pada Gambar 6 terlihat bahwa semakin lama waktu penyimpanan, persentase kadar air tauge kacang hijau semakin menurun. Perubahan kadar air terjadi pada semua perlakuan, baik yang disimpan pada kemasan PE maupun kemasan PP untuk suhu $10^{\circ} \mathrm{C}$ dan suhu $29^{\circ} \mathrm{C}$. Persentase kadar air tertinggi terdapat

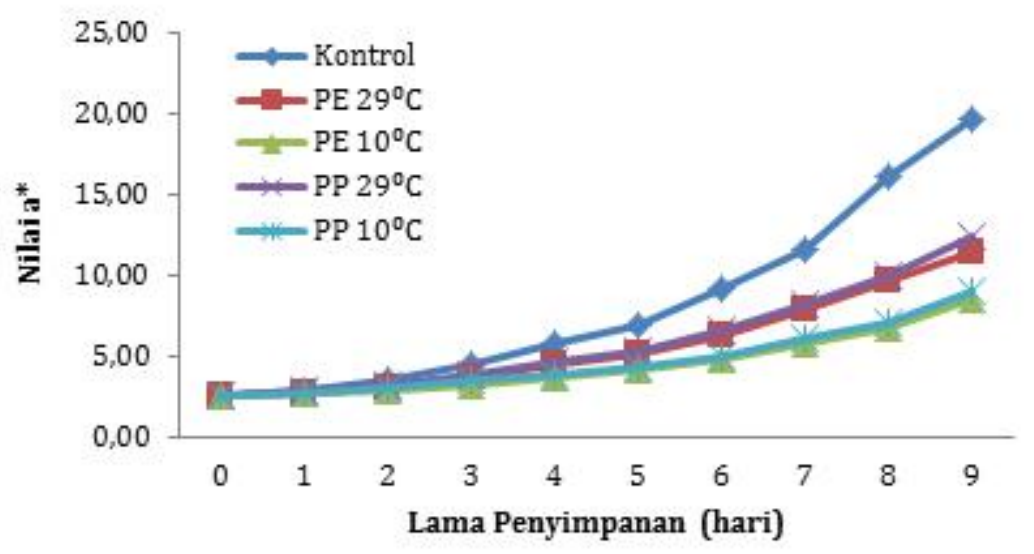

Gambar 4. Hubungan Antara Lama Penyimpanan dengan Kromasitas Hijau-Merah Tauge Kacang Hijau 


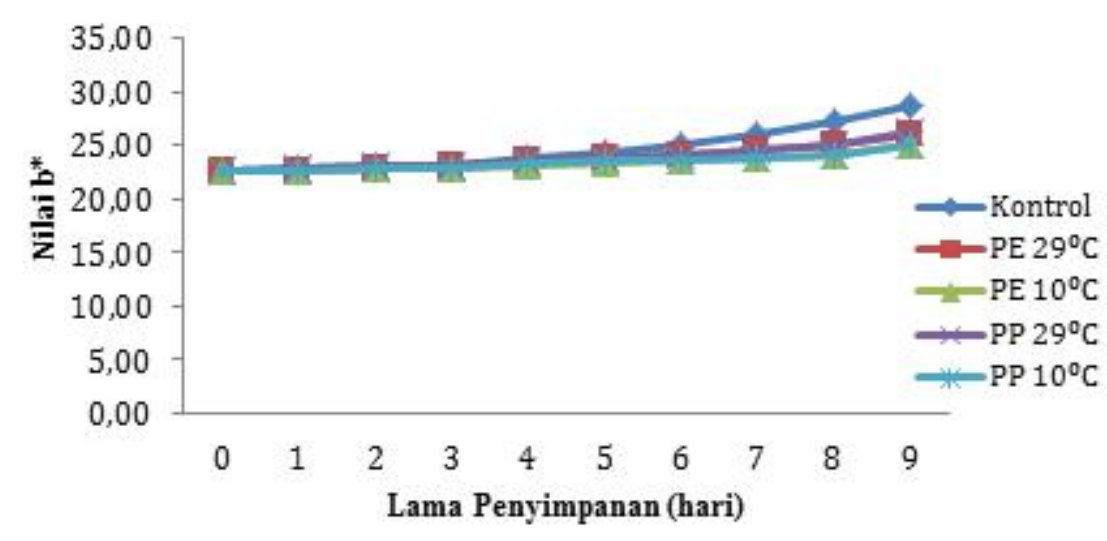

Gambar 5. Hubungan Antara Lama Penyimpanan dengan Kromasitas Kuning-Biru lauge Kacang Hijau

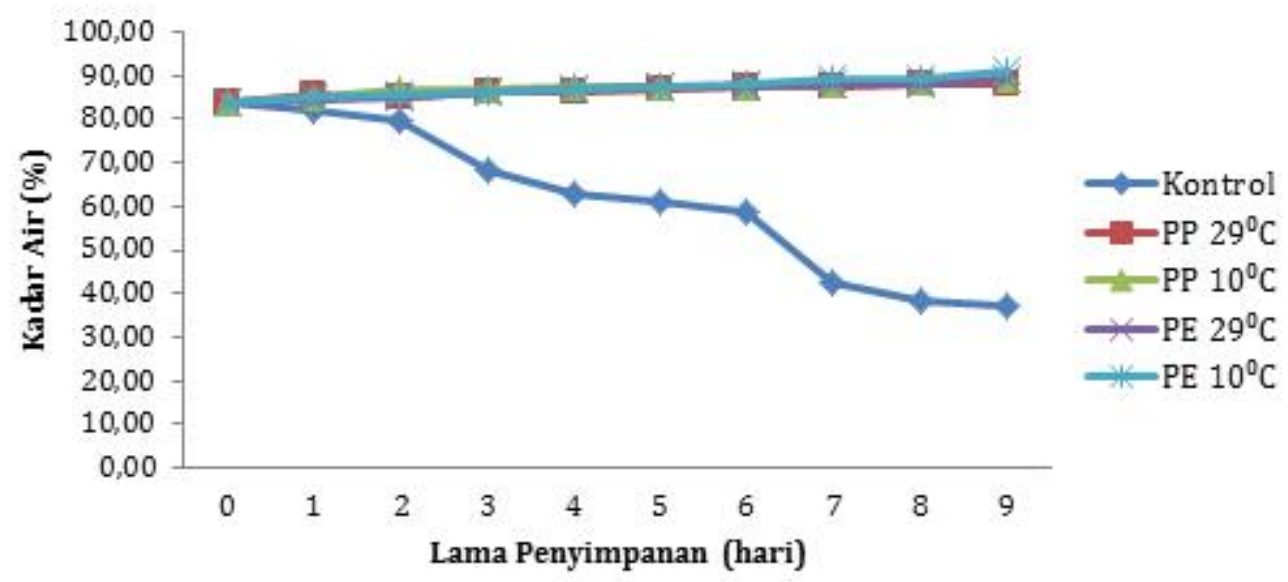

Gambar 6. Hubungan Antara Lama Penyimpanan dengan Kadar Air Tauge Kacang Hijau

pada kemasan $\mathrm{PE}$ dengan suhu $10^{\circ} \mathrm{C}$ yaitu sebesar 90,8\% dan terendah terdapat pada sampel tanpa kemasan yaitu sebesar 37,29\%. Hal ini menunjukkan bahwa penggunaan kemasan PE pada suhu $10^{\circ} \mathrm{C}$ dapat menghambat penguapan air, sehingga kehilangan kadar air pada tauge kacang hijau dapat ditekan jika dibandingkan dengan kemasan PP.

Sedangkan pada sampel tanpa kemasan terjadinya penurunan kadar air yang tinggi karena tidak ada perlindungan antara bahan dengan lingkungan, sehingga proses respirasi dapat berlangsung lebih cepat yang mengakibatkan laju kehilangan air juga semakin cepat. Hasil penelitian yang sama pernah dilaporkan oleh Amanto et al. (2011) bahwa sayuran setelah dipanen masih mengalami perubahan komposisi karena adanya proses metabolisme yang tersebut dengan proses respirasi. Selama proses respirasi produk akan mengkonsumsi $\mathrm{O}_{2}$ dan menghasilkan $\mathrm{CO}_{2}, \mathrm{H}_{2} \mathrm{O}$, dan energi panas yang dihasilkan dari proses respirasi ini dapat memicu terjadinya transpirasi sehingga kadar air akan berkurang.

\subsection{Aroma}

Pada dasarnya aroma merupakan indikator awal konsumen dalam memilih tauge kacang hijau. Aroma yang diterima oleh indera penciuman hidung adalah kombinasi antara empat aroma harum, asem, tengik, dan hangus. Nilai rata-rata uji aroma tauge kacang hijau disajikan pada Gambar 7.

Penilaian rata-rata panelis terhadap aroma tauge kacang hijau paling tinggi terdapat pada kemasan PE dengan penyimpanan suhu $10^{\circ} \mathrm{C}$ yaitu sebesar 4,55 dan nilai rata-rata terendah terdapat pada sampel tanpa kemasan yaitu sebesar 1,00. Penilaian kesukaan panelis menurun karena hilangnya komponen-komponen volatil yang ada pada tauge kacang hijau selama penyimpanan. Hal ini sejalan dengan laporan 


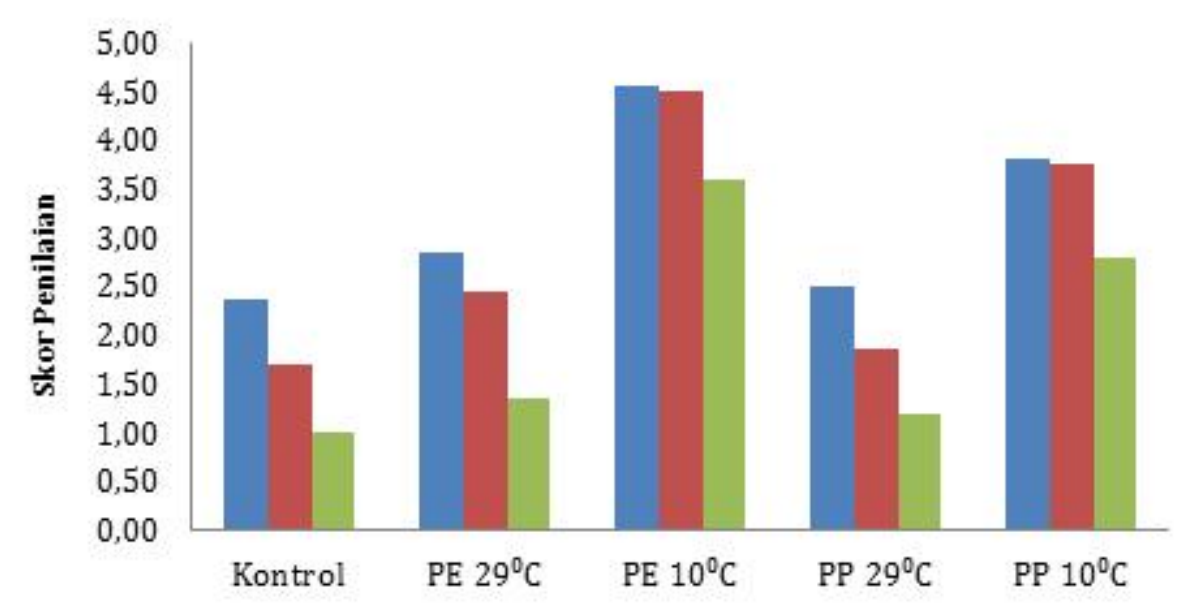

Gambar 7. Hubungan Antara Lama Penyimpanan dengan Aroma Tauge Kacang Hijau

Ansar et al. (2020) bahwa penilaian panelis menurun karena bahan telah mengalami perubahan warna, aroma, rasa, dan tekstur selama penyimpanan.

Aroma yang timbul setelah empat hari pada penyimpanan suhu $29^{\circ} \mathrm{C}$ adalah aroma tauge kacang hijau segar, namun dengan intensitas yang lebih kecil. Pada penyimpanan suhu $10^{\circ} \mathrm{C}$ aroma tauge kacang hijau masih seperti hari pertama pengamatan. Intensitas penurunan aroma tauge kacang hijau dalam kemasan PE lebih rendah daripada kemasan PP. Penurunan intensitas ini disebabkan oleh senyawa volatil yang menimbulkan aroma khas telah menguap. Aroma tauge kacang hijau yang dikemas dalam plastik PE lebih stabil daripada kemasan PP. Hal ini menunjukkan bahwa permeabilitas plastik PE lebih rendah daripada plastik PP.

Hasil pengamatan juga menunjukkan bahwa tauge kacang hijau yang disimpan pada suhu 10 ${ }^{\circ} \mathrm{C}$ relatif lebih baik daripada suhu $29^{\circ} \mathrm{C}$. Hal ini terlihat dari aroma tauge kacang hijau yang disimpan pada suhu $10^{\circ} \mathrm{C}$ lebih terjaga daripada yang disimpan pada suhu $29^{\circ} \mathrm{C}$.

\section{KESIMPULAN DAN SARAN}

\subsection{Kesimpulan}

Susut bobot tertinggi di akhir penyimpanan terdapat pada penyimpanan kontrol dengan nilai sebesar 77,99\%, sedangkan susut bobot terendah terdapat pada suhu penyimpanan 10 ${ }^{\circ} \mathrm{C}$ dengan kemasan PE dengan nilai sebesar
3,70\%. Nilai kecerahan $\left(\mathrm{L}^{*}\right)$ tertinggi terdapat pada kemasan $\mathrm{PE}$ dengan suhu penyimpanan 10 ${ }^{\circ} \mathrm{C}$ dengan nilai sebesar 57,66 , sedangkan nilai kecerahan $\left(\mathrm{L}^{*}\right)$ terendah terdapat pada penyimpanan kontrol dengan nilai sebesar 37,35.

Laju respirasi tertinggi terdapat pada sampel kontrol dengan nilai sebesar $0.97 \mathrm{ml} / \mathrm{jam} / \mathrm{g}$, sedangkan laju respirasi terendah terdapat pada kemasan $P E$ pada suhu penyimpanan $10^{\circ} \mathrm{C}$ yaitu sebesar $0,34 \mathrm{ml} / \mathrm{jam} / \mathrm{g}$. Kadar air tertinggi terdapat pada kemasan PE dengan suhu penyimpanan $10{ }^{\circ} \mathrm{C}$ yaitu sebesar $90,8 \%$, sedangkan kadar air terendah terdapat pada sampel tanpa pengemasan yaitu sebesar 37,29\%. Guna mempertahankan umur simpan tauge kacang hijau, maka perlu dikemas dengan PE dan disimpan pada suhu penyimpanan $10^{\circ} \mathrm{C}$.

\subsection{Saran}

Guna melengkapi data dari penelitian ini, maka disarankan untuk melakukan penelitian lanjutan menggunakan kemasan dan suhu penyimpanan yang berbeda dengan kemasan berlubang dan tidak berlubang.

\section{DAFTAR PUSTAKA}

Akmal, N., Ridhwan, M., Maulidya, F., \& Irdalisa. 2020. Pengaruh penggunaan tauge (Phaseolus radiatus) sebagai sumber nitrogen alternatif dalam pembuatan nata de coco. Jurnal Biology Education, 8(2): 53-61. 
Amanto, B. S., Atmaka, W., \& Rachmawat, D. 2011. Prediksi Umur Simpan Tepung Jagung (Zea mays L.) Instan di dalam Kemasan Plastik. Jurnal Teknologi Hasil Pertanian, 4(2): 74-83.

Anggraini, R., \& Sugiarti, T. 2018. Analisis Pengemasan Jagung Manis (Zea Mays L. Saccharata Sturt) Berkelobot dengan Berbagai Bahan Pengemas. Food Tech Jurnal Teknologi Pangan, 1(1): 25-31.

Ansar, Dwi Putra, G. M., \& Ependi, O. S. 2019. Analisis variasi jenis dan panjang sumbu terhadap pertumbuhan tanaman pada sistem hidroponik. Jurnal Ilmiah Rekayasa Pertanian dan Biosistem, 7(2): 166-173. doi:10.29303/jrpb.v7i2.124.

Ansar, Murad, Sukmawaty, \& Wati, S. 2020. Pengaruh jenis kemasan dan suhu penyimpanan terhadap karakteristik fisik jagung manis segar (Zea mays L.). Jurnal Ilmiah Rekayasa Pertanian dan Biosistem, 8(2): 147-154.

Ansar, Rahardjo, B., Noor, Z., \& Rochmadi. 2011. Influence of temperature and relative humidity on the quality of fruit juice effervescent tablet during storage. Journal of Food Technology and Industry, 22(1): 73-77.

Ansar, Rahardjo, B., Zuheid, N., \& Suyitno. 2006. Optimasi Formula dan Gaya Tekan terhadap Sifat Tablet Effervescent Buah Markisa. Jurnal Teknologi dan Industri Pangan, 17(1): 23-27.

Ansar, Sukmawaty, Putra, G. D., \& Najat, N. H. 2020. Application of Aloe Vera Gel as an Edible Coating at Jackfruit. Jurnal Agritechno, 13(2): 77-83.

Ansar; Cahyawan; Safrani. 2012. Karakteristik Pengeringan Chips Mangga Menggunakan Kolektor Surya Kaca Ganda. Jurnal Teknologi dan Industri Pangan, 23(2): 153-157. doi:10.6066/jitp.2012.23.2.153

Ansar; Nazaruddin; Azis, A D. 2019. Effect of vacuum freeze-drying condition and maltodextrin on the physical and sensory characteristics of passion fruit (Passiflora edulis sims) extract. In Iqbal (Ed.), International Symposium on Agriculture And Biosystem Enginnering. 1, pp. 1-12. Makassar: IOP Conference Series. doi:10.1088/1755-1315/355/1/012067.

Ansar; Nazaruddin; Azis, A D. 2019. Pengaruh Suhu dan Lama Penyimpanan terhadap Perubahan pH dan Warna Nira Aren (Arenga pinnata Merr) setelah Penyadapan. Jurnal Teknik Pertanian Lampung, 8(1): 40-48.

Arrashid, R. A., Haryudo, S. I., Aribowo, W., \& Ibrohim. 2020. Sistem penyiraman tauge menggunakan sumber tenaga hybrid angin dan matahari . Indonesian Journal of Engineering and Technology (INAJET), 2(2): 45-50.

Aulia, S., Ansar, \& Putra , G. D. 2019. Pengaruh intensitas cahaya lampu dan lama penyinaran terhadap pertumbuhan tanaman kangkung(Ipomea reptans poir) pada sistem hidroponik indoor. Jurnal Ilmiah Rekayasa Pertanian dan Biosistem, 7(1): 44-52. doi:10.29303/jrpb.v7i1.100.

Cahyanto, D. D., Hendrawan, Y., \& Djoyowasito, G. 2019. Kinerja Pemisah Kulit Ari Tauge Kacang Hijau (Vigna radiata L.) Berdasarkan Amplitudo Ayakan dan Variasi Putaran. Jurnal Keteknikan Pertanian dan Biosistem, 7(3): 275-284.

Dwi, P. A., Supriyanto , \& Laila, K. M. 2013. Karakteristik jamur tiram (Pleurotusostreatus) selama penyimpanan dalam kemasan plastik polypropilen (PP). Jurnal Agrointek, 7(2): 67-68.

Hasbullah, R. 2007. Teknik pengukuran laju respirasi produk hortikultura pada kondisi atmosfer terkendali bagian 1: metode sistem tertutup. Jurnal Keteknikan Pertanian, 21(4): 419-427.

Imamah, N., Nugroho , L. P., \& Hasbullah , R. 2016. Model Arrhenius untuk Pendugaan Laju 
Respirasi Brokoli Terolah Minimal. Jurnal Keteknikan Pertanian, 4(1): 25-30.

Lamona, A., Purwanto, Y. A., \& Sutrisno . 2015. Pengaruh jenis kemasan dan penyimpanan suhu rendah terhadap perubahan kualitas cabai merah keriting segar. Jurnal Keteknikan Pertanian, 3(2): 145-152.

Lisa, L. H., Putra, B. S., \& Ichwana. 2016. Pengaruh suhu dan umur panen terhadap mutu tauge (Phaseolus radiates) selama penyimpanan dingin. Jurnal Ilmiah Mahasiswa Pertanian Unsyiah, 1(1): 1052-1058.

Mareta, D T; Shofia, N A;. 2011. Pengemasan produk sayuran dengabahan kemas plastik pada penyimpanan suhu ruang dan suhu dingin. Mediagro, 7(1): 26-40.

Mareta, D. T., \& Shofia, N. A. 2011. Pengemasan produk sayuran dengan bahan kemas plastik pada penyimpanan suhu ruang dan suhu dingin. Media Agro, 26-40.

Nurhidajah, \& Kumalasari, D. 2011. Variasi jenis kemasan dan lama penyimpanan pada suhu dingin terhadap kadar vitamin $\mathrm{C}$ dan daya terima jam rosella. Jurnal Pangan dan Gizi, 2(3): 55-66.

Nurmiati, N., \& Gazali, Z. 2019. Pengaruh konsentrasi dan lama perendaman ekstrak tauge (Vigna radiata L.) terhadap perkecambahan terung (Solanum melongena L.). Jurnal Pendidikan Biologi Dan Sains (PENBIOS): 41-46.

Purnomo, E., Suedy, S. A., \& Haryanti, S. 2017. Pengaruh Cara dan Waktu Penyimpanan terhadap Susut Bobot, Kadar Glukosa dan Kadar Karotenoid Umbi Kentang Konsumsi (Solanum tuberosum L. Var Granola). Buletin Anatomi dan Fisiologi, 2(2): 107-113.

Rahmawat, A. 2015. Pengaruh penggunaan plastik polyethylene (PE) dan high density polyethylene (HDPE) pada campuran lataston-WC terhadap karakteristik marshall. Semesta Teknika, 18(2): 147159.

Rina, P. I. 2012. Laju respirasi dan susut bobot buah salak bali segar pada pengemasan plastik polyethylene selama penyimpanan dalam atmosfer termodifikasi. Agrotekno, 15(1): 8-11.

Wulandari, A., Waluyo, S., \& Novita, D. D. 2013. Prediksi umur simpan kerupuk kemplang dalam kemasan plastik polipropilen beberapa ketebalan. Jurnal Teknik Pertanian Lampung, 2(2): 105-114. 